\title{
Response of Mung Bean Crop to Different Levels of Applied Iron and Zinc
}

\author{
Aftab Jamal ${ }^{1,{ }^{*}}$, Muhammad Ismail Khan ${ }^{1}$, \\ Muhammad Tariq ${ }^{1}$ and Muhammad Fawad ${ }^{2}$ \\ ${ }^{1}$ Department of Soil and Environmental Sciences, University of Agriculture, Peshawar, Pakistan \\ ${ }^{2}$ Department of Weed Science, University of Agriculture, Peshawar, Pakistan \\ aftabses98@gmail.com
}

Keywords: Mung bean, Nodules, Fe, Zn.

\begin{abstract}
Fertilization of Mung bean (Vigna radiata L.) is one of the most crucial management technique which effects crop growth and yield. Therefore the present study was carried out at Agricultural Research Station Kohat under rain fed conditions during spring 2017, to assess the response of mung bean (Vigna radiate L.) to three levels of iron $\left(0,2\right.$ and $\left.5 \mathrm{~kg} \mathrm{ha}^{-1}\right)$ and three levels of zinc $\left(0,5\right.$ and $\left.10 \mathrm{~kg} \mathrm{ha}^{-1}\right)$. The experiment was laid out in randomized complete design with split plot arrangement and replicated three times. The results revealed that application of Fe at the rate $5 \mathrm{~kg} \mathrm{ha}^{-1}$ and $\mathrm{Zn}$ at the rate $10 \mathrm{~kg} \mathrm{ha}^{-1}$ significantly increased biological yield, grain yield, straw yield, nodule numbers and weight by $5624 \mathrm{~kg} \mathrm{ha}^{-1}, 968 \mathrm{~kg} \mathrm{ha}^{-1}, 4655 \mathrm{~kg} \mathrm{ha}^{-1}, 35$ and $0.67 \mathrm{~g}$ respectively whereas the interaction was found non-significant. The nitrogen content in grains and straw was also significantly increased by $2.22 \%$ and $3.56 \%$ respectively with application of $\mathrm{Fe}$ at $5 \mathrm{~kg} \mathrm{ha}^{-1}$ and $\mathrm{Zn}$ at $10 \mathrm{~kg} \mathrm{ha}^{-1}$, however their interaction was also found non-significant. Similarly, the plant nitrogen uptake was also significantly increased by $323.33 \mathrm{~kg} \mathrm{ha}^{-1}$ with application of Fe at $5 \mathrm{~kg} \mathrm{ha}^{-1}$ and $\mathrm{Zn}$ at $10 \mathrm{~kg} \mathrm{ha}^{-1}$. It was concluded that $\mathrm{Fe}$ and $\mathrm{Zn}$ enhanced mung bean productivity.
\end{abstract}

\section{Introduction}

Mung bean (Vigna radiata L.) belongs to family Fabaceae and a well known crop of Pakistan enriched in proteins, fibers and in vitamin A [1], Pakistan produced about 93 thousands $t / h a$ of mung bean [2]. In Pakistan, mung bean is grown during July to October and March to June seasons. Although it is grown in different crop rotations, about $75 \%$ cultivation follows mung bean - wheat crop rotation. Punjab is the major mung bean growing province that alone accounted for $88 \%$ area and $85 \%$ of the total mung bean production. [3], however the distinctive feature of mung bean is the root nodules containing nitrogen fixing bacteria Rizobium which in turn improve soil fertility [4], and required lesser irrigation as compared with other field crops [5]. On average annually mung bean can fix about $300 \mathrm{~kg} \mathrm{ha}^{-1}$ atmospheric nitrogen [6]. Despite of its importance mung bean got little attention in Pakistan and yet there is a lot of work to do in improving the quality and quantity of mung bean crop.

A balance fertilization of both macro and micro nutrients are equally important for achieving profitable yield of crops [7]. Iron is an essential nutrient for crop growth involved in chlorophyll synthesis and chloroplast development [8]. Although iron content both in soil and plants are high than $\mathrm{S}$ content and even $\mathrm{P}$, yet its availability is low for plants and hence Fe deficiency is a common problem [9]. So far the role of iron in nodulation and symbiotic nitrogen fixation is not clear, however many investigator reported poor nodulation in absence of $\mathrm{Fe}[10,11]$, but these reports failed to explain the initiation of nodules and development. Iron is a key part of several key proteins like nitrogenase, leghaemoglobin and ferredoxin [12]. Deficiency of iron reduced the initiation as well as development of nodules in legumes [13]. Therefore, the deficiency of iron in legumes is a clear sign of nitrogen deficiency too.

Zinc is a basic micro nutrient and performs several key roles in plant nutrition as well as in human nutrition and its deficiency has an adverse effect on reproductive system [14]. Zn has a dominant role in metabolism of plant hormone called auxin hence promote plant nutrition $[15,16]$. Mung beans are very sensitive to $\mathrm{Zn}$ deficiency in alkaline soil like Pakistan [17]. Many investigators reported Zn deficiency in Pakistani soils [18-20]. 
The importance of $\mathrm{Zn}$ for nodulation and yield of mung bean was also reported by various researchers [21-24]. Similarly, [25] also reported more weight of nodules with application of Zn. Maximum nodulation was reported in lentil at application of $9 \mathrm{~kg} \mathrm{ha}^{-1} \mathrm{Zn}$ [26].

Therefore, keeping in view, the nutritional importance of iron and zinc for mung bean crop, a field experiment was carried out at Kohat Research Station, to evaluate the effect of different levels of $\mathrm{Zn}$ and Fe on mung bean crop.

\section{Materials and Methods}

The experiment was carried out at Agricultural Research Station Kohat under rain fed conditions during spring 2017, to study the effect of iron and zinc on the yield, nodulation and nitrogen uptake by mung bean (Vigna radiate L). Mung bean cultivar $\mathrm{KM}^{-1}$ was used as a test crop. The mung bean seeds were sown in randomized complete design with split plot arrangement and replicated three times. Size of the plot was $3 \times 5 \mathrm{~m}^{2}$. Each plot was comprised of 10 rows containing row to row distance of $30 \mathrm{~cm}$ and plant to plant distance was of $20 \mathrm{~cm}$. Different levels of iron at the rate of 0,2 and $5 \mathrm{~kg} \mathrm{ha}^{-1}$ and zinc at the rate of 0,5 and $10 \mathrm{~kg} \mathrm{ha}^{-1}$ were applied in the form of iron sulfate and zinc sulfate, respectively. A basal dose of $25 \mathrm{~N}, 60 \mathrm{P}_{2} \mathrm{O}_{5}$ and $60 \mathrm{~K}_{2} \mathrm{O} \mathrm{kg} \mathrm{ha}{ }^{-1}$ was also applied in the form of urea, di-ammonium phosphate and potassium sulfate before sowing. These fertilizer doses were calculated according to [2, 26, 32 and 33] with some little modification. Before fertilizer application a composite soil sample was collected for the determination of physiochemical characteristics and desired nutrients status for the test soil. All the agronomic and culture practices were performed. Data on nodules number and nodules weight was recorded at appropriate time (between maximum plant biomass and flowering stage). Five plants were selected randomly from each treatment and carefully uprooted along with soil to avoid damage the roots. Then it was placed in plastic bucket containing water and washed carefully the roots. After washing nodule number was counted on each plant roots. After those nodules were removed from plant roots and weighed by an electronic analytical balance (A balance weighs up to 200 g i.e. 4 decimal places in $\mathrm{g}$, and reads to $0.1 \mathrm{mg}$ ). At maturity stage the plants were harvested to determined biological yield and grain yield. The total-N concentration in straw and grain was determined by Kjeldhal apparatus as described by [27]. The Nitrogen uptake in grain or straw was determined by multiplying their percent concentrations with the corresponding yield. The total nitrogen uptake was obtained by adding up their respective uptake in grain and straw and was expressed in kilogram per hectare. All the data obtained were subjected to Statistix 8.1 software. After that LSD test of significance was used to compare the treatment differences at $\mathrm{P}<0.05$ level of probability.

\section{Results and Discussions}

The physio-chemical attributes of the soil revealed that soil was sandy loam in texture, alkaline in reaction; low in organic matter, calcareous in nature, the zinc and iron content were found low to optimum level (Table 1).

Table 1. Physico-chemical characteristics of soil before mung bean sowing

\begin{tabular}{|l|c|c|}
\hline Physico-chemical properties & Units & Values \\
\hline Sand & $\%$ & 55 \\
\hline Silt & $\%$ & 25 \\
\hline Clay & $\%$ & 20 \\
\hline Textural Class & $\%$ & Sandy loam \\
\hline Organic matter & - & 0.72 \\
\hline $\mathrm{pH}$ & $\%$ & 7.75 \\
\hline Lime & $\mathrm{m} \mathrm{mhos}^{-1}$ & 6.2 \\
\hline EC & $\%$ & 260 \\
\hline Total nitrogen & $\mathrm{ug} \mathrm{g}^{-1}$ & 0.04 \\
\hline Iron & $\mathrm{ug} \mathrm{g}^{-1}$ & 1.51 \\
\hline Zinc & & 0.59 \\
\hline
\end{tabular}




\section{Nodules number}

Number of nodules as influenced by different levels of Fe and $\mathrm{Zn}$ are presented in table 2 . Both $\mathrm{Fe}$ and $\mathrm{Zn}$ applied levels significantly increased the no of nodules. Based on result the maximum no of nodules plant ${ }^{-1}$ of 32 were noticed at application of $\mathrm{Fe}$ at $5 \mathrm{~kg} \mathrm{ha}^{-1}$, similarly $\mathrm{Zn}$ application also improved the no of nodules plant ${ }^{-1}$ linearly from 24 at $0 \mathrm{~kg} \mathrm{ha}^{-1}$ to 30 at $10 \mathrm{~kg} \mathrm{ha}^{-1}$. The interaction effect of $\mathrm{Fe}$ and $\mathrm{Zn}$ was not significantly affecting the number of nodules in mung bean plants. The maximum, 35 nodules plant ${ }^{-1}$ was observed at plot receiving $\mathrm{Fe}$ and $\mathrm{Zn} 5 \mathrm{~kg} \mathrm{ha}^{-1}$ and $10 \mathrm{~kg} \mathrm{ha}^{-1}$ respectively and 20 nodules plant ${ }^{-1}$ at control. Our results was in lined with the published literature it has an established criterion that Fe has dominant effect on nodule formation which ultimately increased the no of nodules plant ${ }^{-1}$. [13] Reported that iron deficiency reduced initiation and development of nodules, similarly [28] also reported positive effect of iron and zinc on number of nodules. Poor nodulation in Lupinus albus L was also reported by [29] in Fe deficient soil. Application of micronutrients (Zn, Fe \& Mo) along with Rhizobium improved nodulation and yield of mung bean [2]. As nodules are the residing place for nitrogen fixing bacteria so it enhances nitrogen fixation in legumes crops.

Table 2. Number of Nodules per plantof mung bean as affected by different levels of Iron and Zinc

\begin{tabular}{|c|c|c|c|c|}
\hline \multirow{2}{*}{$\begin{array}{c}\text { Zn Levels } \\
\left(\mathrm{kg} \mathrm{ha}^{-1}\right)\end{array}$} & \multicolumn{3}{|c|}{------Fe Levels $\left(\mathrm{kg} \mathrm{ha}^{-1}\right)$} & \multirow[b]{2}{*}{ Mean } \\
\hline & $\mathbf{0}$ & 2 & 5 & \\
\hline 0 & 20 & 23 & 29 & $24 \mathrm{c}$ \\
\hline 5 & 23 & 27 & 33 & $28 \mathrm{~b}$ \\
\hline 10 & 25 & 30 & 35 & $30 \mathrm{a}$ \\
\hline Mean & $23 \mathrm{c}$ & $27 \mathrm{~h}$ & $32 \mathrm{a}$ & \\
\hline
\end{tabular}

$\operatorname{LSD}_{(0.05)}$ of Nodules plant ${ }^{-1}$ for $\mathrm{Fe}=394.98$

$\operatorname{LSD}_{(0.05)}$ of Nodules plant ${ }^{-1}$ for $\mathrm{Zn}=655.19$

$\operatorname{LSD}_{(0.05)}$ of Nodules plant ${ }^{-1}$ for $\mathrm{Fe} * \mathrm{Zn}=1134.8$

\section{Weight of nodules (gm)}

The weight of nodules increased simultaneously with the application of both Fe and Zn levels (Table3). Maximum weight of $0.61 \mathrm{gm}$ was recorded at $5 \mathrm{~kg} \mathrm{ha}^{-1} \mathrm{Fe}$ application and $0.57 \mathrm{gm}$ at $10 \mathrm{~kg} \mathrm{ha}^{-1} \mathrm{Zn}$ application. As in table 2, it was cleared that $\mathrm{Fe}$ application speed up the nodule formation which on other hand also increased its weight which is not strange. Our results was also supported by many researchers [30] also resulted increased in weight of nodules with the application of $\mathrm{Zn}$. More nodules formation is associated with micro nutrients application [2].It is an established criterion that Fe deficient crop appeared nitrogen deficiency. The interaction of $\mathrm{Fe}$ and $\mathrm{Zn}$ levels was also significantly increases the weight of nodules. The maximum weight of $0.67 \mathrm{gm}$ was at full dose of Fe and Zn $0.31 \mathrm{gm}$ was observed in control (Table3). Our results were in lined with published literature, [28] stated that $\mathrm{Zn}$ application significantly increased the nodules number and ultimately weight. [10] Reported that Fe application significantly increased the number and weight of nodules. [31] Conformed that $\mathrm{Zn}$ application enhance nodulation which ultimately improve nodules biomass.

Table 3. Weight of Nodules (in grams) of mung bean as affected by different levels of Iron and Zinc

\begin{tabular}{|l|c|c|c|c|}
\hline \multirow{2}{*}{$\begin{array}{c}\text { Zn Levels } \\
\left(\mathrm{kg} \mathrm{ha}^{-1}\right)\end{array}$} & $\mathbf{0}$ & $\mathbf{2}$ & $\mathbf{5}$ & \multirow{2}{*}{ Mean } \\
\cline { 2 - 4 } & 20 & 23 & 29 & $24 \mathrm{c}$ \\
\hline $\mathbf{0}$ & 23 & 27 & 33 & $28 \mathrm{~b}$ \\
\hline $\mathbf{5}$ & 25 & 30 & 35 & $30 \mathrm{a}$ \\
\hline Mean & $23 \mathrm{c}$ & $27 \mathrm{~b}$ & $32 \mathrm{a}$ & \\
\hline
\end{tabular}

$\operatorname{LSD}_{(0.05)}$ of weight of Nodules for $\mathrm{Fe}=0.0235$

$\operatorname{LSD}_{(0.05)}$ of weight of Nodules for $\mathrm{Zn}=0.0311$

$\operatorname{LSD}_{(0.05)}$ of weight of Nodules for $\mathrm{Fe} * \mathrm{Zn}=0.053$ 


\section{Biological yield}

Results revealed that both the Fe and $\mathrm{Zn}$ levels significantly increased the biological yield of mung bean crop over control (Table 4). Iron applied at the rate of $5 \mathrm{~kg} \mathrm{ha}^{-1}$ attributed the maximum biological yield of $4533 \mathrm{~kg} \mathrm{ha}^{-1}$ whereas the minimum of $3541 \mathrm{~kg} \mathrm{ha}^{-1}$ was observed in control. When averaged across the Fe levels, maximum biological yield of $4997 \mathrm{~kg} \mathrm{ha}^{-1}$ was observed in the plots treated with $10 \mathrm{~kg} \mathrm{Zn} \mathrm{ha}^{-1}$ while the minimum biological yield of $3192 \mathrm{~kg} \mathrm{ha}^{-1}$ was noted in untreated plots. The interactive effect of $\mathrm{Fe}$ and $\mathrm{Zn}$ was observed non-significant. The maximum biological yield of $5624 \mathrm{~kg} \mathrm{ha}^{-1}$ was noted in the plots receiving 5 and $10 \mathrm{~kg} \mathrm{ha}^{-1} \mathrm{Fe}$ and $\mathrm{Zn}$ respectively whereas the lowest yield of $2823 \mathrm{~kg} \mathrm{ha}^{-1}$ was observed in control (Table 4). Many researchers reported significant increase in yield with the application of different levels of Fe. [11, 32] also reported an increase in biomass with the application of micro nutrients ( $\mathrm{Zn}, \mathrm{B}, \mathrm{Mo}, \mathrm{Fe}$ ) different levels. [33] Concluded the same results in mung bean. [34] Stated that micronutrients play important role in growth and yield of legumes. [35] Reported that applied levels of $(\mathrm{Fe}+\mathrm{Zn})$ combine and zinc alone significantly increased the crop yield.

Table 4. Biological yield $\left(\mathrm{kg} \mathrm{ha}^{-1}\right)$ of mung bean as affected by different levels of Iron and Zinc

\begin{tabular}{|l|c|c|c|c|}
\hline \multirow{2}{*}{$\begin{array}{c}\text { Zn Levels } \\
\left(\text { kg ha }^{-1}\right)\end{array}$} & $\mathbf{0}$ & $\mathbf{2}$ & $\mathbf{5}$ & \multirow{2}{*}{ Mean } \\
\cline { 2 - 4 } & 2823 & 3010 & 3743 & $3192 \mathrm{c}$ \\
\hline $\mathbf{0}$ & 3634 & 3944 & 4233 & $3937 \mathrm{~b}$ \\
\hline $\mathbf{5}$ & 4167 & 5200 & 5624 & $4997 \mathrm{a}$ \\
\hline $\mathbf{1 0}$ & $3541 \mathrm{c}$ & $4051 \mathrm{~b}$ & $4533 \mathrm{a}$ & \\
\hline Mean & &
\end{tabular}

$\mathrm{LSD}_{(0.05)}$ of BY for $\mathrm{Fe}=406.47$

$\operatorname{LSD}_{(0.05)}$ of $\mathrm{BY}$ for $\mathrm{Zn}=646.13$

$\operatorname{LSD}_{(0.05)}$ of BY for $\mathrm{Fe}^{*} \mathrm{Zn}=1119.1$

\section{Grain yield}

Grain yield was significantly increased with increasing levels of $\mathrm{Fe}$ and $\mathrm{Zn}$ (Table 5). On average maximum grain yield of $636 \mathrm{~kg} \mathrm{ha}^{-1}$ was obtained from the plots treated with high dose $5 \mathrm{~kg} \mathrm{ha}^{-1}$ of $\mathrm{Fe}$ which was significantly higher than control. Results regarding $\mathrm{Zn}$ levels showed a significant increased in grain yield with each increment. On average, maximum grain yield of $743 \mathrm{~kg} \mathrm{ha}^{-1}$ was observed in the plots treated with $10 \mathrm{~kg} \mathrm{ha}^{-1} \mathrm{Zn}$. The interactive effect of Fe and $\mathrm{Zn}$ was also significant. On average, the maximum grain yield of $968 \mathrm{~kg} \mathrm{ha}^{-1}$ was obtained for the treatment receiving $\mathrm{Fe}$ at $5 \mathrm{~kg} \mathrm{ha}^{-1}$ and $\mathrm{Zn} 10 \mathrm{~kg} \mathrm{ha}^{-1}$ (Table5 and Fig.1). Many published literatures confirmed the results. [36] Reported an increase of $28.1 \%$ of mung bean grain yield with $\mathrm{Zn}$ fertilization as compared with control. $\mathrm{Zn}$ application improves the growth and quality parameters in mung bean $[22,37]$. Increased in grain yield of mung bean with application of $\mathrm{Zn}$ and $\mathrm{Mg}$ was also reported by [38]. Foliar application of iron significantly increased the grain yield of mung bean [39]. Iron and zinc application increased the grain yield either applied to soil or applied as foliar spray $[40,41]$.

Table 5. Grain yield as $\left(\mathrm{kg} \mathrm{ha}^{-1}\right)$ of mung bean as affected by different levels of Iron and Zinc

\begin{tabular}{|l|c|c|c|c|}
\hline \multirow{2}{*}{$\begin{array}{c}\text { Zn Levels } \\
\left(\mathbf{k g ~ h a}^{-1}\right)\end{array}$} & $\mathbf{0}$ & $\mathbf{2}$ & $\mathbf{5}$ & \multirow{2}{*}{ Mean } \\
\cline { 2 - 5 } & $303 \mathrm{e}$ & $328 \mathrm{e}$ & $378 \mathrm{e}$ & $336 \mathrm{c}$ \\
\hline $\mathbf{0}$ & $407 \mathrm{de}$ & $528 \mathrm{~cd}$ & $562 \mathrm{c}$ & $499 \mathrm{~b}$ \\
\hline $\mathbf{1 0}$ & $517 \mathrm{~cd}$ & $745 \mathrm{~b}$ & $968 \mathrm{a}$ & $743 \mathrm{a}$ \\
\hline Mean & $409 \mathrm{c}$ & $534 \mathrm{~b}$ & $636 \mathrm{a}$ & \\
\hline
\end{tabular}

$\operatorname{LSD}_{(0.05)}$ of $\mathrm{GY}$ for $\mathrm{Fe}=98.152$

$\operatorname{LSD}_{(0.05)}$ of $\mathrm{GY}$ for $\mathrm{Zn}=59.868$

$\mathrm{LSD}_{(0.05)}$ of $\mathrm{GY}$ for $\mathrm{Fe}^{*} \mathrm{Zn}=103.69$ 


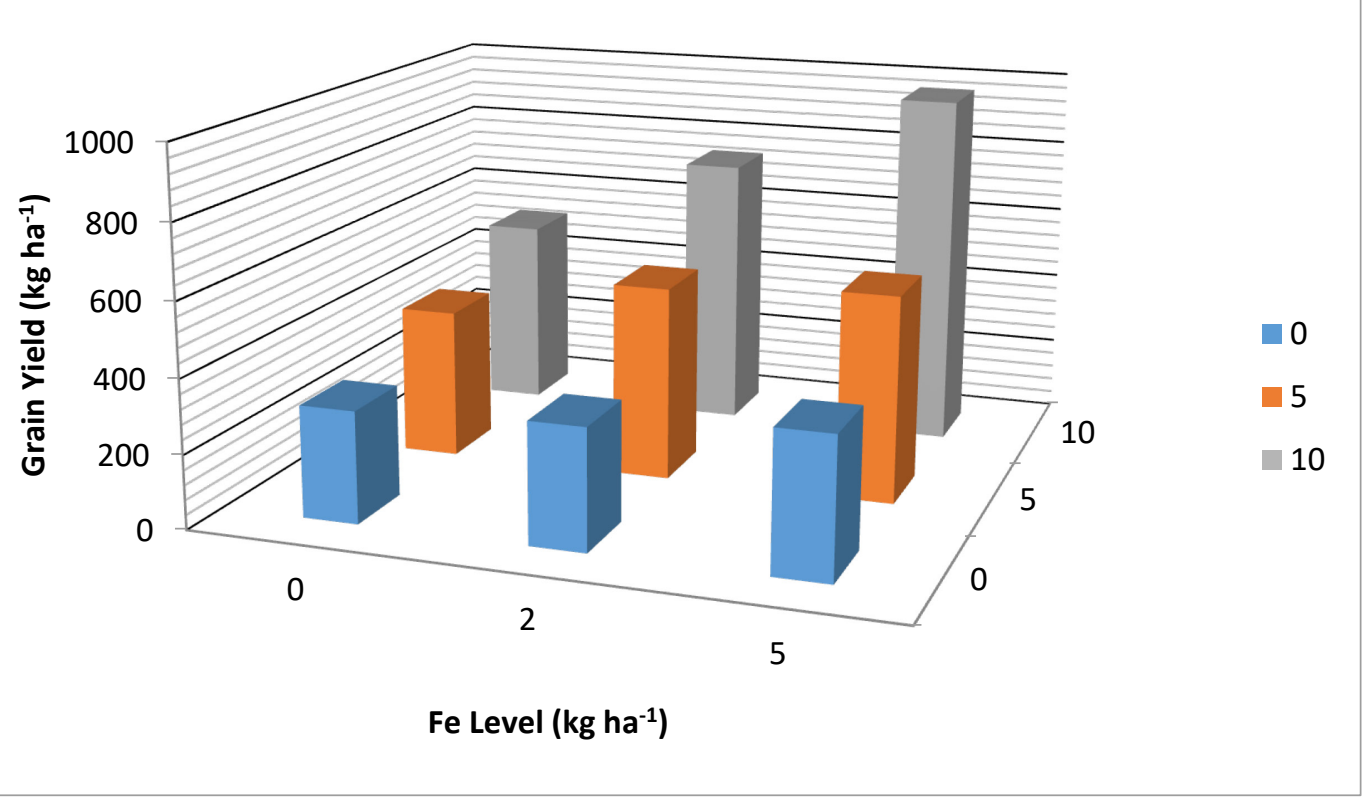

Figure 1. Grain yield as $\left(\mathrm{kg} \mathrm{ha}^{-1}\right)$ of mung bean as affected by different levels of Iron and Zinc

\section{Straw yield}

On average, maximum straw yield of $3897 \mathrm{~kg} \mathrm{ha}^{-1}$ was obtained from the plots treated with high dose of $5 \mathrm{~kg} \mathrm{ha}^{-1}$ of applied $\mathrm{Fe}$ that was statistically similar to the plot receiving $\mathrm{Fe}$ dose at $2 \mathrm{~kg} \mathrm{ha}^{-1}$ while significantly higher than the control (Table 6). Zinc application at different levels increased the straw yield of mung bean crop significantly. On average, maximum straw yield of $4253 \mathrm{~kg} \mathrm{ha}^{-1}$ was observed in the plots treated with $10 \mathrm{~kg} \mathrm{ha}^{-1} \mathrm{Zn}$ and the minimum $2856 \mathrm{~kg} \mathrm{ha}^{-1}$ was without $\mathrm{Zn}$ application. However, the interactive effect of $\mathrm{Fe}$ and $\mathrm{Zn}$ was found non-significant. Maximum straw yield of $4655 \mathrm{~kg} \mathrm{ha}^{-1}$ was recorded from treatment containing $\mathrm{Fe}$ at $5 \mathrm{~kg} \mathrm{ha}^{-1}$ and $\mathrm{Zn}$ at $10 \mathrm{~kg} \mathrm{ha}^{-1}$ and that was statistically similar for the treatments receiving Fe at $2 \mathrm{~kg} \mathrm{ha}^{-1}$ and $\mathrm{Zn}$ $10 \mathrm{~kg} \mathrm{ha}^{-1}$ and the minimum yield of $2520 \mathrm{~kg} \mathrm{ha}^{-1}$ was observed in control (Table 6). The result was corroborated with published values; [42] reported that Fe levels significantly increased the straw yield of cowpea. [33] Concluded that the seed and Stover yield of mung bean significantly increased over control by the application of Fe. Micro nutrients application can increase the straw yield of mung bean [43].

Table 6. Straw yields $\left(\mathrm{kg} \mathrm{ha}^{-1}\right)$ of mung bean as affected by different levels of Iron and Zinc

\begin{tabular}{|l|c|c|c|c|}
\hline \multirow{2}{*}{$\begin{array}{c}\text { Zn Levels } \\
\left(\mathbf{k g ~ h a}^{-1}\right)\end{array}$} & \multicolumn{2}{|c|}{-------Fe Levels (kg ha $\left.{ }^{-1}\right)-----$} & \multirow{2}{*}{ Mean } \\
\cline { 2 - 4 } & 2520 & $\mathbf{2}$ & $\mathbf{5}$ & $2856 \mathrm{~b}$ \\
\hline $\mathbf{0}$ & 3227 & 2682 & 3365 & $3438 \mathrm{~b}$ \\
\hline $\mathbf{5}$ & 3650 & 3415 & 4672 & $4253 \mathrm{a}$ \\
\hline $\mathbf{1 0}$ & $3133 \mathrm{~b}$ & 4455 & 3655 & \\
\hline Mean & & $3517 \mathrm{ab}$ & $3897 \mathrm{a}$ & \\
\hline
\end{tabular}

$\operatorname{LSD}_{(0.05)}$ of $\mathrm{SY}$ for $\mathrm{Fe}=394.98$

$\operatorname{LSD}_{(0.05)}$ of SY for $\mathrm{Zn}=655.19$

$\operatorname{LSD}_{(0.05)}$ of SY for $\mathrm{Fe}^{*} \mathrm{Zn}=1134.8$

\section{Grain Nitrogen (\%)}

Both Iron and $\mathrm{Zn}$ application significantly increased the nitrogen content in mung bean grain (Table 7). Iron levels significantly affect the nitrogen content. Maximum nitrogen of $3.35 \%$ was recorded at $5 \mathrm{~kg} \mathrm{ha}^{-1} \mathrm{Fe}$ application and minimum of $2.95 \%$ was at control. Zn levels showed a significant increase in grain nitrogen with each increment. On average, maximum nitrogen content of $3.35 \%$ was observed in the plots treated with $10 \mathrm{~kg} \mathrm{ha}^{-1}$ and minimum of $2.92 \%$ was at without $\mathrm{Zn}$ application. The interaction of applied $\mathrm{Fe}$ and $\mathrm{Zn}$ was found non-significant effect on grain 
nitrogen content of mung bean. The maximum nitrogen of $3.56 \%$ was recorded at 5 and $10 \mathrm{~kg} \mathrm{ha}^{-1}$ applied Fe and $\mathrm{Zn}$ respectively and minimum of $2.65 \%$ was at control. Our results were in lined with [22, 44, 45, 23, 46 and 47] who reported increased in grain nitrogen with application of $\mathrm{Zn}$ fertilization. Similarly, [2] also confirmed that $N$ content in mung bean increased with micronutrients (Zn, Fe \& Mo) application.

Table 7. Grain Nitrogen conc (\%) of mung bean as affected by different levels of Iron and Zinc

\begin{tabular}{|l|c|c|c|c|}
\hline \multirow{2}{*}{$\begin{array}{c}\text { Zn Levels } \\
\left(\text { kg ha }^{-1}\right)\end{array}$} & \multicolumn{2}{|c|}{-------Fe Levels (kg ha $\left.\mathbf{~}^{-1}\right)----$} & \multirow{2}{*}{ Mean } \\
\cline { 2 - 4 } & $\mathbf{0}$ & $\mathbf{2}$ & $\mathbf{5}$ & $2.92 \mathrm{~b}$ \\
\hline $\mathbf{5}$ & 2.65 & 2.97 & 3.13 & $3.17 \mathrm{ab}$ \\
\hline $\mathbf{1 0}$ & 2.99 & 3.17 & 3.36 & $3.35 \mathrm{a}$ \\
\hline Mean & 3.20 & 3.28 & 3.56 & \\
\hline
\end{tabular}

$\operatorname{LSD}_{(0.05)}$ of Gain $\mathrm{N}$ for $\mathrm{Fe}=0.3532$

$\operatorname{LSD}_{(0.05)}$ of Gain $\mathrm{N}$ for $\mathrm{Zn}=0.2664$

$\mathrm{LSD}_{(0.05)}$ of Gain $\mathrm{N}$ for $\mathrm{Fe} * \mathrm{Zn}=0.4614$

\section{Straw nitrogen concentration $(\%)$}

Straw Nitrogen content as affected by different levels of Fe and $\mathrm{Zn}$ are presented in table 13. Both Iron and $\mathrm{Zn}$ application significantly increased the mung bean straw nitrogen. Iron levels significantly affect the nitrogen content. Maximum \% Nitrogen of $1.82 \%$ was recorded $5 \mathrm{~kg} \mathrm{ha}^{-1} \mathrm{Fe}$ application and minimum of $1.51 \%$ was at control. Results regarding $\mathrm{Zn}$ levels showed a significant increase in straw nitrogen with each increment. On average, maximum nitrogen content of $1.89 \%$ was observed in the plots treated with $10 \mathrm{~kg} \mathrm{ha}^{-1}$ and minimum was at without $\mathrm{Zn}$ application. The interaction of applied $\mathrm{Fe}$ and $\mathrm{Zn}$ was found non-significant. The maximum \% nitrogen of $2.22 \%$ was recorded at 5 and $10 \mathrm{~kg} \mathrm{ha}^{-1}$ applied $\mathrm{Fe}$ and $\mathrm{Zn}$ respectively and minimum of $1.35 \%$ was at control. Published literature revealed that iron application increased the $\mathrm{N}$ content of plants. [2] Reported that $\mathrm{N}$ content in mung bean plant increased by micronutrients ( $\mathrm{Zn}, \mathrm{Fe} \&$ Mo) application. Zn application reduced the $\mathrm{P}$ content however it increased crop nitrogen content [23].

Table 8. Straw Nitrogen (\%) concentrations of mung bean as affected by different levels of Iron and Zinc

\begin{tabular}{|l|c|c|c|c|}
\hline \multirow{2}{*}{$\begin{array}{c}\text { Zn Levels } \\
\left(\mathrm{kg} \mathrm{ha}^{-1}\right)\end{array}$} & \multicolumn{2}{|c|}{-------Fe Levels (kg ha $\left.{ }^{-1}\right)----$} & \multirow{2}{*}{ Mean } \\
\cline { 2 - 4 } & $\mathbf{0}$ & $\mathbf{2}$ & $\mathbf{5}$ & $1.47 \mathrm{c}$ \\
\hline $\mathbf{5}$ & 1.35 & 1.51 & 1.55 & $1.63 \mathrm{~b}$ \\
\hline $\mathbf{1 0}$ & 1.52 & 1.66 & 2.22 & $1.89 \mathrm{a}$ \\
\hline Mean & 1.66 & 1.82 & $1.82 \mathrm{a}$ & \\
\hline
\end{tabular}

$\operatorname{LSD}_{(0.05)}$ of straw $\mathrm{N}$ for $\mathrm{Fe}=1.7988$

$\operatorname{LSD}_{(0.05)}$ of straw $\mathrm{N}$ for $\mathrm{Zn}=3.2957$

$\operatorname{LSD}_{(0.05)}$ of straw $\mathrm{N}$ for $\mathrm{Fe}^{*} \mathrm{Zn}=5.7084$

\section{Total nitrogen (Straw+Grain) uptake}

Both Iron and $\mathrm{Zn}$ application significantly increased the nitrogen uptake in mung bean crop. Iron levels significantly affect the nitrogen uptake. Maximum nitrogen uptake of $238.06 \mathrm{~kg} \mathrm{ha}^{-1}$ was recorded $5 \mathrm{~kg} \mathrm{ha}^{-1} \mathrm{Fe}$ application and minimum of $160.34 \mathrm{~kg} \mathrm{ha}^{-1}$ was at control (Table 9). Results regarding $\mathrm{Zn}$ levels showed a significant increase in nitrogen uptake with each increment. On average, maximum nitrogen content of $263.99 \mathrm{~kg} \mathrm{ha}^{-1}$ was observed in the plots treated with $10 \mathrm{~kg}$ $\mathrm{ha}^{-1}$ and minimum of $141.58 \mathrm{~kg} \mathrm{ha}^{-1}$ was at $0 \mathrm{~kg} \mathrm{ha}^{-1}$ applied $\mathrm{Zn}$. The interaction effect of applied Fe and $\mathrm{Zn}$ was found non-significant. The maximum nitrogen uptake of $323.33 \mathrm{~kg} \mathrm{ha}^{-1}$ was recorded at 5 and $10 \mathrm{~kg} \mathrm{ha}^{-1}$ applied $\mathrm{Fe}$ and $\mathrm{Zn}$ respectively and minimum of $141.58 \mathrm{~kg} \mathrm{ha}^{-1}$ was at control. Published literature revealed that iron application increased the $\mathrm{N}$ uptake of plants .Our result was similar to the findings of $[48,49]$. 
Table 9. Plant Nitrogen (Straw + Grain) uptake as $\left(\mathrm{kgha}^{-1}\right)$ of mung bean as affected by different levels of Iron and Zinc

\begin{tabular}{|l|c|c|c|c|}
\hline \multirow{2}{*}{$\begin{array}{c}\text { Zn Levels } \\
\left(\text { kg ha }^{-1}\right)\end{array}$} & $\mathbf{0}$ & $\mathbf{2}$ & $\mathbf{5}$ & \multirow{2}{*}{ Mean } \\
\cline { 2 - 4 } & 113.72 & 135.02 & 176.01 & $141.58 \mathrm{c}$ \\
\hline $\mathbf{0}$ & 164.00 & 190.39 & 214.82 & $189.74 \mathrm{~b}$ \\
\hline $\mathbf{5}$ & 203.30 & 265.33 & 323.33 & $263.99 \mathrm{a}$ \\
\hline Mean & $160.34 \mathrm{c}$ & $196.91 \mathrm{~b}$ & $238.06 \mathrm{a}$ & \\
\hline
\end{tabular}

$\mathrm{LSD}_{(0.05)}$ of plant $\mathrm{N}$ for $\mathrm{Fe}=23.168$

$\operatorname{LSD}_{(0.05)}$ of plant $\mathrm{N}$ for $\mathrm{Zn}=32.809$

$\operatorname{LSD}_{(0.05)}$ of plant $\mathrm{N}$ for $\mathrm{Fe} * \mathrm{Zn}=56.826$

\section{Conclusions}

From the investigation it was concluded that application of $\mathrm{Fe}$ and $\mathrm{Zn}$ at the rate of 5 and $10 \mathrm{~kg} \mathrm{ha}^{-1}$ respectively significantly enhanced the biological, grain, straw yields, number and weight of nodules of mung bean. Maximum uptake of nitrogen by the plants straw and grain was also observed in the plots where $\mathrm{Fe}$ and $\mathrm{Zn}$ were applied at higher rate of $5 \mathrm{~kg} \mathrm{ha}^{-1}$ and $10 \mathrm{~kg} \mathrm{ha}^{-1}$ respectively. Such studies are suggested to evaluate the effect of iron and zinc for various leguminous crops under different agro-ecological zones to improve the nitrogen fixation.

\section{Conflict of Interest}

The authors declare that there is no conflict of interest.

\section{References}

[1] A. Tabassum, M. Saleem, I. Aziz, Genetic variability, trait association and path analysis of yield and yield components in mung bean [Vigna radiata (L.) Wilezeek], Pakistan Journal of Botany. 42 (2000) 3915-3924.

[2] I. Ahmad et al., Influence of rhizobium applied in combination with micronutrients on mungbean, Pakistan Journal of Life and Social Sciences. 11(1) (2013) 53-59.

[3] Pakistan Agriculture Research Council PARC. 2009. National coordinated pulses program NARC, Islamabad.

[4] M. Ashraf, M. Mueen-Ud-Din, N. Warrich, Production efficiency of mungbean (Vigna radiata L) as affected by seed inoculation and NPK application, Int. J. Agric. Biol. 5(2) (2003) 179180.

[5] G.S.S. Khattak et al., A new high yielding mungbean (Vigna radiata (L.) Wilczek) variety" Ramzan" for the agro climatic conditions of NWFP, Pakistan Journal of Botany. 38(2) (2006) 301.

[6] M.S. Sharar et al., Effect of different row spacing and seeding densities on the growth and yield of gram (Cicer arietinum L.), Pak. J. Agric. Sci. 38 (2001) 51-53.

[7] Z.M. Sawan, S.A. Hafez, A.E. Basyony, Effect of phosphorus fertilization and foliar application of chelated zinc and calciumon seed, protein and oil properties of cotton, Journal of Agriculture sciences. 136 (2001) 191-198.

[8] A.K. Saini, R. Singh, Effect of sulphur and iron fertilization on growth and yield of greengram [Vigna radiata L.], Int. J. Curr. Microbiol. App. Sci. 6(6) (2017) 1922-1929.

[9] T. Nozoye et al., Phytosiderophone efflux transporters are crucial for iron acquisition in graminaceous plants, J. Bio. Chem. 286 (2011) 5446-5454. 
[10] P. Balachander, P. Nagarajan, S. Gunasekaran, Effect of organic amendments and micronutrients on nodulation and yield of black gram in acid soil, Legumes Res. 26 (2003) 192-195.

[11] U. Thapu et al., Effect of micronutrients on the growth and yield of pea in gangetic alluvial of west Bengal, Environ. Ecol. 21 (2003) 179-182.

[12] K.K. Pingoliya, M.L. Dotaniya, M. Lata, Effect of iron on yield, quality and nutrient uptake of chickpea (Cicer arietinum L.), Afr. J. Agric. Res. 9(37) (2014) 2841-2845.

[13] E.M. Brear, D.A. Day, P.M.C. Smith, Iron: an essential micronutrient for the legumerhizobium symbiosis, Frontiers in Plant Science. 4 (2013) 359.

[14] M. Kaya et al., Effect of pre-sowing seed treatment with zinc and foliar spray of humic acids on yield of common bean (Phaseolus vulgaris L.), Int. J. Agric. Biol. 7 (2005) 875-878.

[15] E. Penas et al., Effect of combined treatments of high pressure, temperature and antimicrobial products on germination of mungbean seeds and microbial quality of sprouts, Food Cont. 21 (2010) 82-88.

[16] M.S.A. Ahmad et al., Photosynthetic performance of two mung bean (Vigna radiata L.) cultivars under lead and copper stress, Int. J. Agric. Biol. 10 (2008) 167-172.

[17] G. Jayne, Mungbean Management Guide, 2nd Ed., 2010. https://www.daff.qld.gov.au/_data/assets/pdf_file/0005/57623/mung-manual2010-LR.pdf. Accessed: 01 February 2015.

[18] W. Ahmad et al., Zinc deficiency in soils, crops and humans: a review, Agrochimica. 56(2) (2012) 65-97.

[19] S.G. Khattak, P.J. Dominy, W. Ahmad, Effect of Zn as soil addition and foliar application on yield and protein content of wheat in alkaline soil, Journal of the National Science Foundation of Sri Lanka. 43(4) (2015).

[20] M.A. Kauser et al., Zinc and $\mathrm{Cu}$ nutrition of two wheat varieties on a calcareous soil, Pakistan Journal of Soil Science. 20 (2001) 21-26.

[21] I.U. Rahman et al., Response of common bean (Phaseolus vulgaris) to basal applied and foliar feeding of different nutrients application, American-Eurasian J. Agric. \& Environ. Sci. 14(9) (2014) 851-854.

[22] J.R. Thomas et al., Widespread deficiencies of sulfur, boron and zinc in Indian semi-arid tropical oils: On-farm crop responses, J. Plant Nutr. 30 (2007) 1569-1583.

[23] M.A. Hossain, M. Jahiruddin, F. Khatun, Response of maize varieties to zinc fertilization, Bangl. J. Agric. Res. 36 (2011) 437-447.

[24] E.A. Ali, A.M. Mahmoud, Effect of foliar spray by different salicylic acid and zinc concentrations on seed yield and yield components of mungbean in sandy soil, Asian J. Crop Sci. 5 (2013) 33-40.

[25] M.A. Quddus et al., Effect of zinc and boron on yield and yield contributing characters of mungbean in low ganges river floodplain soil at Madaripur, Bangladesh, Bangladesh Journal of Agricultural Research. 36(1) (2011) 75-85.

[26] A. Ali et al., Effect of phosphorus and zinc on yield of lentil, Pure and Applied Biology (PAB). 6(4) (2017) 1397-1402.

[27] R.L. Mulvaney, Nitrogen-inorganic forms, in: D.L. Sparks (Ed.), Methods of soil analysis, Part 3, Am. Soc. Agron. 38 (1996) 1123-1184. 
[28] S. Kobraee, K. Shamsi, S. Ekhtiari, Soybean nodulation and chlorophyll concentration (SPAD value) affected by some of micronutrients, Annals of Biological Research. 2(2) (2011) 414422.

[29] C. Tang et al., Interactions between high $\mathrm{pH}$ and iron supply on nodulation and iron nutrition of Lupinus albus L. genotypes differing in sensitivity to iron deficiency, Plant and Soil. 279(1-2) (2006) 153-162.

[30] R.G. Upadhyay, A. Singh, Effect of nitrogen and zinc on nodulation, growth and yield of cowpea (Vigna unguiculata), Legume Research-An International Journal. 39(1) (2016) 149151.

[31] A.S. Abdulameer, Impact of rhizobial strains mixture, phosphorus and zinc applications in nodulation and yield of bean (Phaseolus vulgaris L.), Baghdad Sci. J. 1(8) (2011) 358-364.

[32] K.D. Meveda, J.J. Patel, K.P. Patel, Effect of micronutrients on yield of urdbean, Indian J. Pulse Res. 18 (2005) 214-216.

[33] P.S. Yadav, P.R. Kameriya, S. Rathore, Effect of phosphorus and iron fertilization on yield, protein content and nutrient uptake in mungbean on loamy sand soil, J. Indian Soc. Soil Sci. 50 (2002) 225-226.

[34] M. Ali et al., Growth and yield response of hybrid maize through integrated phosphorus management, Pakistan Journal of Life and Social Sciences. 10 (2012) 59-66.

[35] A. Yassen, E.A. El-Nour, S. Shedeed, Response of wheat to foliar spray with urea and micronutrients, Journal of American Science. 6(9) (2010) 14-22.

[36] M. Kaya, R. Karaman, A. Şener, Influence of different zinc application methods on yield and mineral composition of grains in mungbeans (Vigna radiata Wilczek), International Journal of Agriculture \& Biology. 19(4) (2017) 805-811.

[37] T. Samreen et al., Zinc effect on growth rate, chlorophyll, protein and mineral contents of hydroponically grown mungbeans plant (Vigna radiata), Arabian Journal of Chemistry. 10 (2017) S1802-S1807.

[38] A.T. Thalooth, M.M. Tawfik, H. Magda Mohamed, A comparative study on the effect of foliar application of zinc, potassium and magnesium on growth, yield and some chemical constituents of mungbean plants grown under water stress conditions, World Agric. Sci. 2 (2006) 37-46.

[39] M.H. Al-Issawi, O.H. Mahdi, Foliar application of iron and potassium enhances growth and yield of mung bean (Vigna radita L.), Diyala Agricultural Sciences Journal. 8(2) (2016) 4355.

[40] M. Seilsepour, The study of Fe and $\mathrm{Zn}$ effects on quantitative and qualitative parameters of winter wheat and determination of critical levels of these elements in Varamin plain soils, Pajouhesh \& Sazandegi. 76 (2007) 123-133.

[41] M. Habib, Effect of foliar application of $\mathrm{Zn}$ and $\mathrm{Fe}$ on wheat yield and quality, African Journal of Biotechnology. 8 (2009) 6795-6798.

[42] V. Kumar, V.N. Dwivedi, D.D. Tiwari, Effect of phosphorus and iron on yield and mineral nutrition in chickpea, Ann. Plant Soil Res. 11 (2009) 16-18.

[43] P.K. Salam et al., Effect of micronutrients fertilization on productivity potential of urdbean (Phaseolus mungo L.), Ann. Agric. Res. New Series. 25 (2004) 329-332.

[44] M.A. Hossain et al., The requirement of zinc for improvement of crop yield and mineral nutrition in the maize-mungbean-rice system, Plant Soil. 306 (2008) 13-22. 
[45] M. Kaya, Z. Küçükyumuk, İ. Erdal, Phytase activity, phytic acid, zinc, phosphorus and protein contents in different chickpea genotypes in relation to nitrogen and zinc fertilization, Afr. J. Biotechnol. 8 (2009) 4508-4513.

[46] F. Sönmez et al., Effects of zinc, salt and mycorrhiza applications on the development and the phosphorus and zinc uptake of maize, Yüzüncü Yıl Üniversitesi Tarım Bilimleri Dergisi J. Agric. Sci. 23 (2013) 1-9.

[47] P.D. Roy et al., Impact of zinc application methods on green gram (Vigna radiata L.) productivity and grain zinc fortification, J. Environ. Biol. 35 (2014) 851-854.

[48] R.N. Kumawat, P.S. Rathore, N. Pareek, Response of moongbean to S and Fe nutrition grown on calcareous soil of Western Rajasthan, Indian Journal of Pulse Research. 19(2) (2006) 228230.

[49] K.K. Meena, R.S. Meena, S.M. Kumawat, Effect of sulphur and iron fertilization on yield attributes, yield and nutrient uptake of mungbean (Vigna radiata), Indian Journal of Agricultural Science. 83(4) (2013) 472-476. 